\title{
The Effect of Transformational Leadership and Organizational Support on Member Performance and Its Impact on Performance: Study in Kodam Iskandar Muda
}

*Mahesa Fitriadi, Muhammad Adam, Mukhlis

Program Studi Magister Manajemen, Universitas Syiah Kuala, 23111, Indonesia

DOI - http://doi.org/10.37502/IJSMR.2021.4513

\begin{abstract}
This study is to examine and analyze the effect of transformational leadership and organizational support on member performance and its impact on organizational performance. The object is the Military Command (Kodam) Iskandar Muda which operates in Aceh. The population is as much as 412 personnel, and the sample is taken based on the staratified random sampling method, which results in a number of 320 respondents, and researchers add it to be 350 respondents. The research model is analyzed using Structural Equation Modeling (SEM) with the help of Amos software. The results finds that transformational leadership significantly affects the performance of members, organizational support significantly affects the performance of members, transformational leadership significantly affects performance of the Kodam Iskandar Muda, organizational support significantly affects performance of the Kodam Iskandar Muda, the member performance significantly affects performance of the Kodam Iskandar Muda Kodam, transformational leadership affects performance of the Kodam Iskandar Muda through member performance, and organizational support affects performance of the Kodam Iskandar Muda through member performance. These findings contribute academically, especially in the renewal of the theory of causality and can be a reference for practical leaders, especially those in the Kodam Iskandar Muda. The novelty of this research lies in the combination of previous causality research models, with new objects. The limitation of the study is the number of variables studied and the scope of the study.
\end{abstract}

Keyword: Transformational Leadership, Organizational Support, Individual Performance, Organizational Performance.

\section{Introduction}

The Iskandar Muda Military Command (Kodam Iskandar Muda) is the main command of coaching at the level of the army headquarters which is directly under the Kasad and the 
operational main command at the level of the Indonesian National Armed Forces (TNI) Headquarters which is located directly under the TNI commander. The existence of the very strategic Kodam headquarters must be examined and evaluated in terms of its indicators and strategic plans so that the Kodam Iskandar Muda as an organization can go in a direction and achieve the targets set with the support of the performance of all members of the TNI and other supporting elements.

As the main command of development, the existence of the Kodam Iskandar Muda must carry out a number of basic tasks and functions as stipulated in the Regulation of the Army Chief of Staff No. 69 of 2017 concerning the organization and duties of the regional military command. With these regulations it is hoped that members and headquarters of the Kodam as an organization can carry out their main duties and functions properly.

The performance of the TNI members at the Kodam Iskandar Muda Headquarters according to some officials' level of view of the assistant is not optimal, especially related to the dynamics of the development of internal and external environmental threats that always affect almost all organizations, including at the Kodam Iskandar Muda Headquarters. Many factors are expected to influence the performance of an organization whose existence and development are quite dynamic. Member performance refers to member achievements that can be measured based on established standards or criteria. Common criteria for evaluating member / employee performance can be seen from the individual tasks assigned, their behavior, and their individual characteristics. These three things determine the way employees in completing the work given (Robbins \& Judge, 2012). Many references that stated about the individual performance, employee performance, or staff performance, which in this study are called member performance. (Fahmi, Musnadi, \& Nadirsyah, 2019) revealed that employee performance affects organizational performance at the Nagan Raya District Inspectorate. (Ritonga, Ibrahim, \& Bahri, 2019) explained that the leadership style influences the performance of DJKN Aceh. (Ihya, Adam, \& Nurdin, 2019) also proved that employee performance affects organizational performance in the BKKBN Aceh. Thus, member performance is one of the variables that needs to be examined in this study.

The performance of members of the Indonesian National Army (TNI) on the Kodam Iskandar Muda based on observations still needs to be improved, especially to keep up with the demands of its very dynamic and strategic role. However, institutionally the TNI organization at the Kodam Iskandar Muda headquarter is very solid and should be proud of. Judging from the main tasks and functions, the presence of members is not yet fully capable of completing their duties and responsibilities as an important element in the operation of national defense and security in the region.

TNI members at the Iskandar Muda Kodam headquarters are also aware that they are not yet fully capable of planning and developing themselves as reliable forces. Members are also still weak in preparing work plans. This can be seen from the way of working members who are still lacking in planning, and members have not been able to realize the work plans that have been set 
previously. Thus, the expected performance achievement is less than optimal and not as expected. The ability of members to provide services to the community is also still low.

The low performance of TNI members is influenced by several factors identified by researchers, including those related to the leadership style and organizational support felt by each TNI member in the Kodam Iskandar Muda. The style of leadership chosen and applied is one of the determining factors for an organization's success. In carrying out its leadership function, a leader cannot be separated from the existence of a leadership style. This style aims to lead to compliance for those who work for an organization to meet and in accordance with the direction of the leader (Anwar, 2012). One of the leadership styles in question is transformational leadership. Transformational leadership is defined as a process of mutual enhancement between leaders and followers to a higher level of morality and motivation (Yukl, 2010).

In addition to the transformational leadership factor, an organization also needs organizational support for its members. Organizational support internally also has a connection in the implementation of a soldier's duty in maintaining the integrity and sovereignty of his territory. (Chiang \& Hsieh, 2012) stated that organizational support is able to improve and provide effectiveness in improving performance. To find out the condition of organizational support felt by members, there are two aspects namely: organizational appreciation for member contributions, and; organizational attention to member welfare. (Chiang \& Hsieh, 2012) stated that there are three important aspects of organizational support that members can feel, namely: (a) Justice, (b) Superiors/Leaders' Support, and (c) Rewards from the organization and working conditions.

\section{Literature Study}

\section{Organizational Performance}

According to (Pasolong, 2010) organizational performance is the overall effectiveness of the organization for the needs that are determined from each group regarding through systematic efforts and continuously improving the organization's ability to achieve their needs effectively. In this study, the mention of organizational performance is equated with the performance of the Kodam Iskandar Muda, where the Kodam Iskandar Muda is the object name of the organization under study.

The organizational performance indicators for the Kodam Iskandar Muda can refer to organizational indicators in general, which are based on the main duties and functions of the Iskandar Muda Kodam which are regulated in the regulation of the army chief of staff number 69 in 2017. Its main function as an indicator of organizational performance is (1) The ability to build strength, territorial defense in the land and maintain national security in the region. (2) Ability to carry out defense / security operations of the landmass in the region. (3) The ability to fight as a ground force. (4) Ability to plan, develop, mobilize and control the potential of defense areas. (5) The ability of investigation, security and raising. (6) Ability to carry out the planning, operation, training and readiness of the Kodam unit. (7) Ability to provide education, use, care 
and separation of personnel. (8) Capability in the fields of supply, maintenance, transportation, logistics administration, and the administration and arrangement of BMN. (9) Ability to carry out territorial development activities (10) Ability in the formulation of plans, implementation, and program and budget control. (11) Ability in the field of supervision and general inspection and differences.

\section{Individual (Member) Performance}

Every employee in the organization is required to make a positive contribution through good performance, considering the performance of the organization depends on the performance of its employees (Gibson, Ivancevic, \& Konopaske, 2012). Performance is not just about achieving results but broadly need to pay attention to other aspects, as defined by (Prawirosentono, 2010), performance is the result of work that can be achieved by a person or group of people in an organization, in accordance with their respective authorities and responsibilities, in the context of achieving the objectives of the organization concerned legally, does not violate the law and is in accordance with morals and ethics. Especially for public institutions, such a definition of performance is a concern in order to be able to carry out functions and roles according to the rules and set an example for others.

In this study, the performance of members, or the performance of members of the TNI (Indonesian National Army), is equated with the understanding of individual performance, where the TNI is an individual who carries out tasks at the Kodam Iskandar Muda. The performance of members (TNI) of the Kodam Iskandar Muda is an individual performance which is the result of quality and quantity of work achieved by a TNI member. (Dessler, 2003) stated that basically performance is more a function of training, communication, tools and supervision as well as personal motivation, performance goals and standards must be in accordance with the strategic objectives of the organization/agency.

Based on opinion (Robbins \& Judge, 2012) that work performance or individual work performance of an organization is a person's work ability in achieving the stated goals. The indicators of employee performance are: (1) Quality, (2) Quantity, (3) On time, (4) Utilizing resources, (5) Independence and (6) Responsibility.

\section{Transformational Leadership}

(Hasibuan, 2014) stated that the leader is someone who uses his authority and leadership to direct others and is responsible for the work of that person in achieving a goal. Transformational leadership is included in the theory of the situation, is a leadership that has a vision and is able to identify changes in the environment and be able to transform these changes into the organization, spearheading change and motivating and inspiring individual employees to be creative and innovative, bring renewal in management performance, be brave and is responsible for leading and controlling the organization (Usman, 2012). (Gibson et al., 2012) stated that transformational leaders are able to motivate their followers to work towards a goal, not for short-term personal interests, and to achieve performance and self-actualization, not for the sake of feeling safe. 
In this study the transformational leadership indicators use (Avolio, Bass, \& Jung, 1999) in (Ling, Lo, Sing, \& Ayob, 2010) namely: (1) The ability to direct to give respect and confidence in facing challenges (idealized influence), (2) The ability to provide inspiration and motivation to achieve the certain performance (inspirational motivation), (3) The ability to provide ideas for career development and performance (intellectual simulation), (4) The ability to listen attentively and give special attention to subordinates (individualized consideration).

\section{Organizational Support}

(Darolia, Kumari, \& Darolia, 2010) explained that organizational support is very instrumental in determining the performance of members. In his research also explained that organizational support is related to work performance, where awards by the organization are considered to provide benefits for members, such as work comfort because they are accepted and recognized, get salaries and promotions, get information easily, as well as several other things that members need to be able to carry out their work effectively. The perception of organizational support is influenced by various aspects of employee treatment by the organization, which in turn will affect the employee's interpretation of the organization that underlies the treatment motive (Kurtessis et al., 2015).

Several indicators of organizational support were expressed by (Kurtessis et al., 2015) namely: (1) Awards; the company gives awards / rewards for employee work achievement, (2) Development; the company pays attention to capabilities and provides promotional opportunities for employees, (3) working conditions; regarding physical and non-physical work environments, (4) employee welfare; the company cares about the welfare of employees' lives.

\section{Research Paradigm}

Based on the discussion of the problem and research literature, the researcher formulates the paradigm and research hypothesis as follows. 


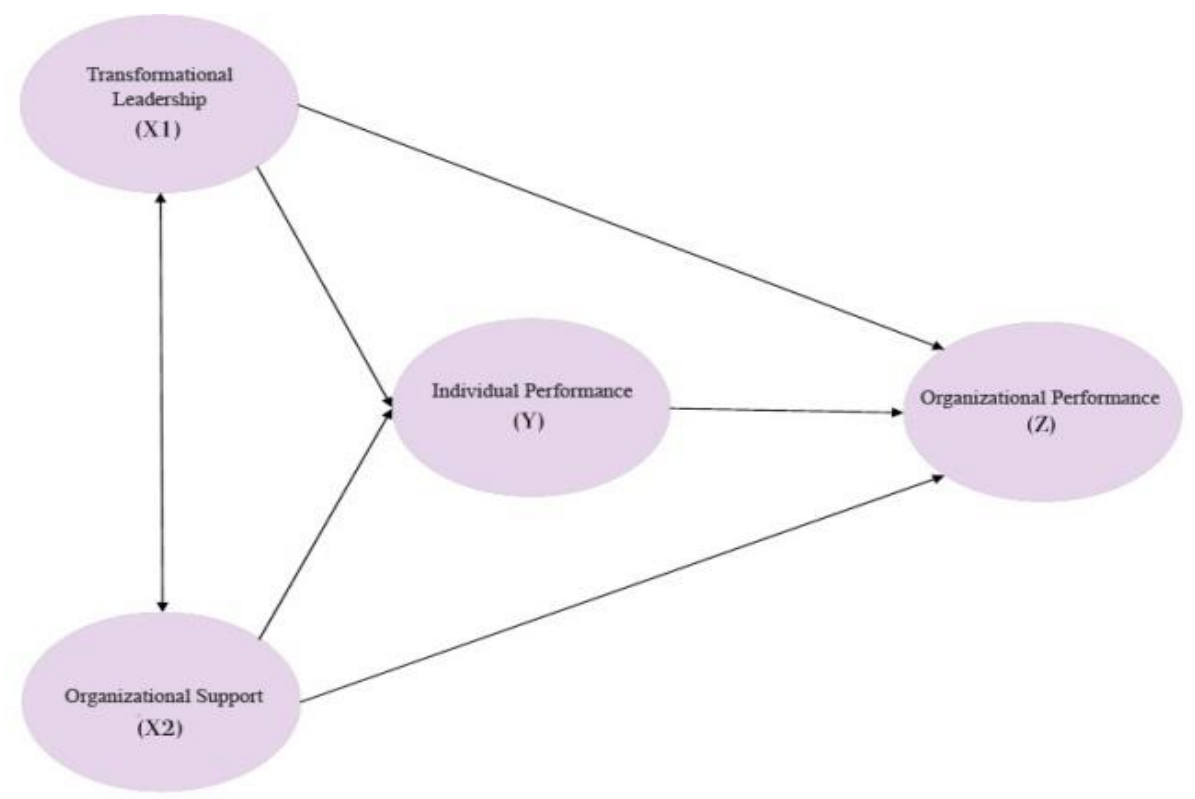

Figure 1. Research Model

\section{Hypothesis}

$\mathrm{H}_{\mathrm{a} 1}$ : Transformational leadership affects member performance significantly

$\mathrm{H}_{\mathrm{a} 2}$ : Organizational support affects member performance significantly.

$\mathrm{H}_{\mathrm{a} 3}$ : Transformational leadership affects performance of Kodam Iskandar Muda significantly

$\mathrm{H}_{\mathrm{a} 4}$ : Organizational support affects performance of the Iskandar Muda Kodam significantly

$\mathrm{H}_{\mathrm{a} 5}$ : Member performance affects Kodam Iskandar Muda significantly

$\mathrm{H}_{\mathrm{a} 6}$ : Transformational leadership affects performance of the Kodam Iskandar Muda through member performance significantly.

$\mathrm{H}_{\mathrm{a} 7}$ : Organizational support affects performance of the Kodam Iskandar Muda through member performance significantly.

\section{Research Method}

This research is conducted at the Kodam Iskandar Muda that is located in Aceh, Indonesia. The variables are transformational leadership, organizational support, individual performance and organizational performance. Individual performance, which in this case is the performance of TNI members at the Kodam Iskandar Muda, is to mediate the performance of the Kodam Iskandar Muda organization.

The study population is all members of the Indonesian National Army who served at the Kodam Iskandar Muda, as much as 412 personnel. Because this research is not a census study, the researcher conducted a sample withdrawal. Determination of the sample is done by the stratified random sampling method, which means that members of the TNI who are at the Kodam Iskandar Muda are stratified according to their ranks in each area of duty. Referring to 
suggestions for the needs of the model that will be used, namely sampling based on 10 times the indicators used, 320 members are needed as samples taken randomly from members of the population in each task area. To be more convincing, in this study the authors set a sample size greater than the demands of 10 times the indicator, ie 350 samples chosen by staratified random sampling.

Data is collected using questionnaires. The list of questions is asked and assessed using a Likert scale. Data analysis tools used in this study were Structural Equation Modeling (SEM) with the help of Amos software. The SEM equation model is a collection of statistical techniques that allow the simultaneous testing of a series of relatively complex relationships (Ferdinand, 2006). SEM is able to enter latent variables into the analysis. To test mediation variables, this study uses the Sobel test.

In this study, authors build constructs for each variable studied based on previous theories, and the conditions that bind the measurement of organizational performance under study, namely:

(1) Organizational Performance: (1) The ability to build strength, territorial defense in the land and maintain national security in the region. (2) Ability to carry out defense / security operations of the landmass in the region. (3) The ability to fight as a ground force. (4) Ability to plan, develop, mobilize and control the potential of defense areas. (5) The ability of investigation, security and raising. (6) Ability to carry out the planning, operation, training and readiness of the Kodam unit. (7) Ability to provide education, use, care and separation of personnel. (8) Capability in the fields of supply, maintenance, transportation, logistics administration, and the administration and arrangement of BMN. (9) Ability to carry out territorial development activities (10) Ability in the formulation of plans, implementation, and program and budget control. (11) Ability in the field of supervision and general inspection and differences.

(2) Member Performance: (1) Quality, (2) Quantity, (3) On time, (4) Utilizing resources, (5) Independence and (6) Responsibility.

(3) Transformational leadership : (1) The ability to direct to give respect and confidence in facing challenges (idealized influence), (2) The ability to provide inspiration and motivation to achieve the certain performance (inspirational motivation), (3) The ability to provide ideas for career development and performance (intellectual simulation), (4) The ability to listen attentively and give special attention to subordinates (individualized consideration).

(4) Organization Support: (1) Awards, (2) Development (3) working conditions, (4) employee welfare.

\section{Results and Discussion}

Structural model analysis that explains the test of influence between variables is presented in the following path diagram: 


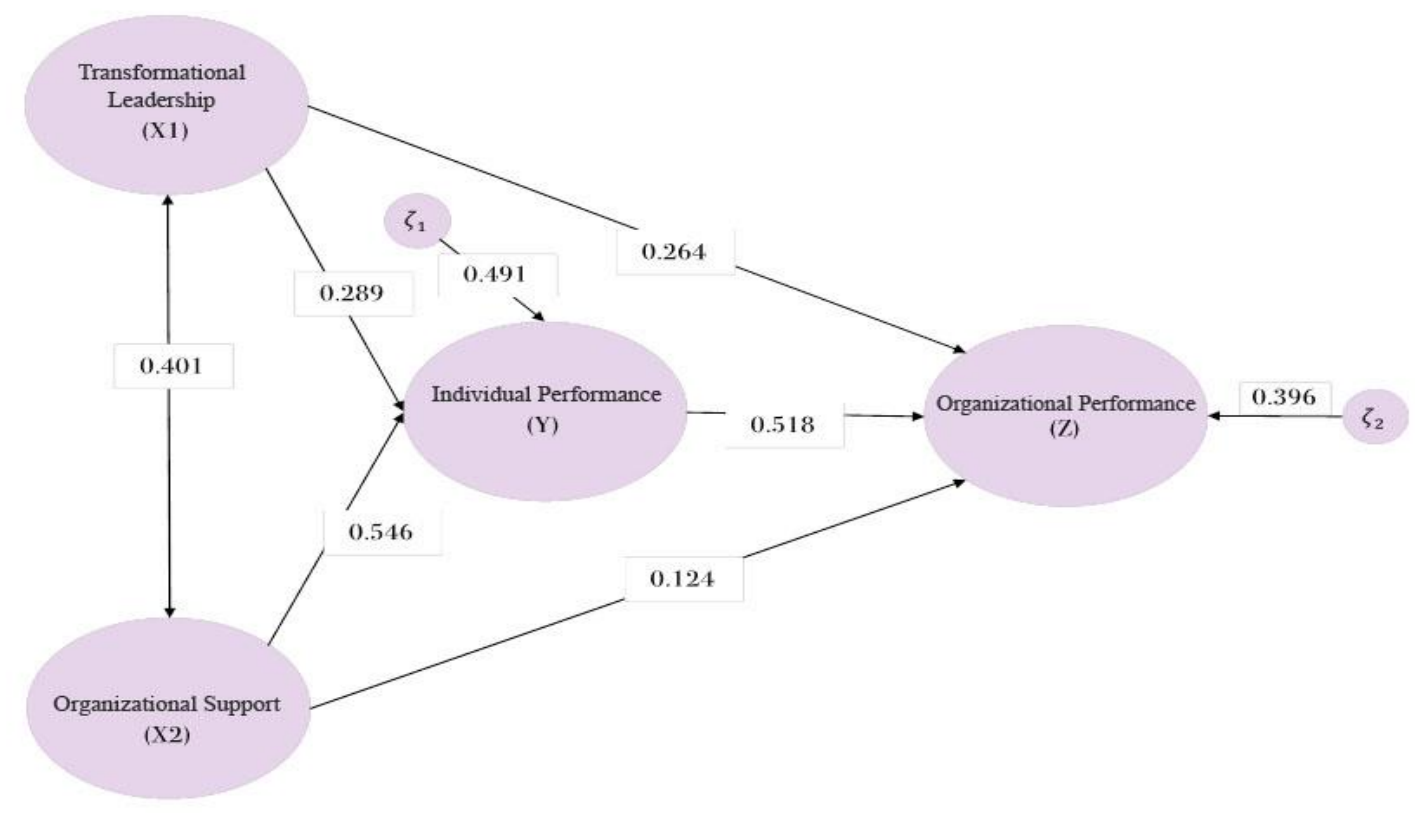

Figure 2. SEM Analysis Result

The result of the analysis proves that the variable of transformational leadership and organizational support have a positive influence on the member performance. The effect of organizational support is found to be greater than transformational leadership. The influence of organizational support amounted to 0.546 while the influence of leadership amounted to 0.289. These results indicate that improvements in organizational support will have a greater effect on changes in member performance. The calculation of the coefficient of determination results a value of $1-0.491=0.519$. The coefficient of determination $51.9 \%$ illustrates that $51.9 \%$ of the diversity of member performance is explained by the variables of transformational leadership and organizational support.

Furthermore, the direct effect of the member performance variable is found to be the greatest influence on the performance of the Kodam Iskandar Muda organization with the influence of 0.518 .

Table 1. Direct Effect of Transformational Leadership and Organizational Support on Member Performance

\begin{tabular}{|l|c|c|c|}
\hline \multicolumn{1}{|c|}{ Influence } & Coefficient & z-value & $\mathrm{P}(>|\mathrm{z}|)$ \\
\hline Transformational leadership $\rightarrow$ Member Performance & 0.289 & 4.292 & 0.000 \\
\hline Organizational Support $\rightarrow$ Member Performance & 0.546 & 7.669 & 0.000 \\
\hline
\end{tabular}

The result of hypothesis testing using the $\mathrm{z}$ test statistic gives a p.value of 0.000 for the influence of transformational leadership and organizational support on member performance. These results conclude that there is a significant influence of leadership variables and 
organizational support on the performance of member at the Kodam Iskandar Muda headquarters.

The following presents the results of the analysis of transformational leadership, organizational support and member performance on the organizational performance of the Kodam Iskandar Muda. The direct effect of the member performance variable is found to be the greatest influence on the performance of Kodam Iskandar Muda with the coefficient 0.518, then the second largest influence is the transformational leadership variable with the coefficient 0.264 while the organizational support variable directly only has an effect with its coefficient 0.124. Furthermore, to find out whether the effect of each variable is significant or not, the hypothesis tests result as shown in the following table:

Table 2. Direct Effect of Transformational Leadership, Organizational Support and Member Performance on Organizational Performance

\begin{tabular}{|l|c|c|c|}
\hline \multicolumn{1}{|c|}{ Influence } & Coefficient & $\mathrm{z}$-value & $\mathrm{P}(>|\mathrm{z}|)$ \\
\hline Transformational leadership $\rightarrow$ Organizational performance & 0.264 & 3.837 & 0.000 \\
\hline Organizational Support $\rightarrow$ Organizational performance & 0.124 & 2.106 & 0.035 \\
\hline Member Performance $\rightarrow$ Organizational performance & 0.518 & 7.625 & 0.000 \\
\hline
\end{tabular}

The $\mathrm{z}$ test statistic calculation results all influences have $\mathrm{p}$ values $<0.05$. It means that all influences are significant. Thus, it concludes that there is a significant influence of transformational leadership, organizational support and member performance on the performance of the Kodam Iskandar Muda.

After verifying the direct influence hypotheses, the following is presented an analysis of the indirect effect of transformational leadership and organizational support on the performance of the Kodam Iskandar Muda through member performance. The result using structural equation modeling (SEM) proves that the variable that have the most indirect effect on organizational performance is organizational support with a large influence of 0.283 and the transformational leadership variable gives effect of 0.150 .

\section{Table 3. Indirect Effect of Transformational Leadership and Organizational Support on Organizational Performance through Member Performance}

\begin{tabular}{|l|c|c|c|}
\hline \multicolumn{1}{|c|}{ Influence } & $\begin{array}{l}\text { Coeffici } \\
\text { ent }\end{array}$ & $\begin{array}{l}\mathrm{z}- \\
\text { value }\end{array}$ & $\begin{array}{l}\mathrm{P}(>\mid \mathrm{z} \\
\mid)\end{array}$ \\
\hline $\begin{array}{l}\text { Transformational leadership } \rightarrow \text { Member Performance } \rightarrow \\
\text { Organizational Performance }\end{array}$ & 0.150 & 3.610 & $\begin{array}{c}0.00 \\
0\end{array}$ \\
\hline $\begin{array}{l}\text { Organizational Support } \rightarrow \text { Member Performance } \rightarrow \text { Organizational } \\
\text { Performance }\end{array}$ & 0.283 & 5.006 & $\begin{array}{c}0.00 \\
0\end{array}$ \\
\hline
\end{tabular}

The results finds that all indirect effects of transformational leadership and organizational support on the performance of the Kodam Iskandar Muda through member performance have a $p$ 
value $<0.050$ so the null hypothesis is rejected which means that there is an indirect effect of transformational leadership and organizational support on performance of Kodam Iskandar Muda through member performance. Thus, it describes that the member performance variable is a mediating variable.

Thus, the results of the hypothesis test in this study can be concluded as follows:

Table 4. Hypothesis Test Results

\begin{tabular}{|c|c|c|}
\hline & Hypothesis & $\begin{array}{l}\text { The } \\
\text { Results }\end{array}$ \\
\hline $\begin{array}{l}\mathrm{H} \\
1\end{array}$ & Transformational leadership $\rightarrow$ Individual Performance & accepted \\
\hline $\begin{array}{l}\mathrm{H} \\
2\end{array}$ & Organizational Support $\rightarrow$ Individual Performance & accepted \\
\hline $\begin{array}{l}\mathrm{H} \\
3\end{array}$ & Transformational leadership $\rightarrow$ Organizational Performance & accepted \\
\hline $\begin{array}{l}\mathrm{H} \\
4\end{array}$ & Organizational Support $\rightarrow$ Organizational Performance & accepted \\
\hline $\begin{array}{l}\mathrm{H} \\
5\end{array}$ & Individual Performance $\rightarrow$ Organizational Performance & accepted \\
\hline $\begin{array}{l}\mathrm{H} \\
6\end{array}$ & $\begin{array}{l}\text { Kepemimpinan transformasional } \rightarrow \text { Individual Performance } \rightarrow \text { Organizational } \\
\text { Performance }\end{array}$ & accepted \\
\hline $\begin{array}{l}\mathrm{H} \\
7\end{array}$ & $\begin{array}{l}\text { Organizational Support } \rightarrow \text { Individual Performance } \rightarrow \text { Organizational } \\
\text { Performance }\end{array}$ & accepted \\
\hline
\end{tabular}

1. There is a positive and significant influence of the variable of transformational leadership on the performance of members of the TNI Kodam Iskandar Muda. The positive influence explains that the more transformational leadership felt by members of the TNI, their performance will also increase. One indicator that is considered to be improved related to the transformational leadership is the ability of leaders to direct members to be respectful and have high confidence in facing any challenges.

2. There is a positive and significant influence of the organizational support on the performance of members of Kodam Iskandar Muda. The result reveals that the better organizational support will also be able to improve member performance and even higher member performance is influenced by organizational support compared to transformational leadership.

3. Transformational leadership isls found to have a positive and significant effect on the performance of the Kodam Iskandar Muda. The positive influence shows the improvement in transformational leadership will drive the increase in the performance of the Kodam Iskandar Muda. The influence exerted is smaller than the influence of 
transformational leadership on member performance because in the process of improving organizational performance requires performance member as mediator.

4. There is a positive and significant influence from the variables of organizational support on the performance of the Kodam Iskandar Muda Kodam. The direct effect of organizational support is lower than leadership on organizational performance due to the need for member performance moderator variable to be able to significantly improve organizational performance.

5. Member performance variable is the variable that has the greatest influence on organizational performance. The result of hypothesis testing finds that there is a positive and significant effect of the members' performance on the performance of the Kodam Iskandar Muda. These result indicates a link between member performance and organizational performance.

6. Transformational leadership significantly influences the performance of the Kodam Iskandar Muda organization which is mediated by performance. This significant result proves that the effect of transformational leadership on the performance of the Kodam Iskandar Muda is getting stronger with the encouragement of member performance. Thus, member performance cannot be separated from the model as a mediating variable.

7. Organizational support has a significant effect on organizational performance of the Kodam Iskandar Muda, which is mediated by performance. Significant result indicates that the effect of organizational support for the performance of the Kodam Iskandar Muda is getting stronger with the encouragement of member performance. Thus, member performance cannot be separated from the model as a mediating variable.

\section{Conclusions}

The results finds that transformational leadership significantly affects the performance of members, organizational support significantly affects the performance of members, transformational leadership significantly affects performance of the Kodam Iskandar Muda, organizational support significantly affects performance of the Kodam Iskandar Muda, the member performance significantly affects performance of the Kodam Iskandar Muda Kodam, transformational leadership affects performance of the Kodam Iskandar Muda through member performance, and organizational support affects performance of the Kodam Iskandar Muda through member performance. These findings contribute academically, especially in the renewal of the theory of causality and can be a reference for practical leaders, especially those in the Kodam Iskandar Muda. The novelty of this research lies in the combination of previous causality research models, with new objects. The limitation of the study is the number of variables studied and the scope of the study.

This study mapped the managerial implications for handling the organization of the Iskandar Muda Kodam in the future. Related to leadership, leaders are expected to be able to direct subordinates to give respect and confidence in facing challenges. Self confidence is an important part of every TNI member to be able to complete their duties properly in accordance 
with the assigned target. High confidence will accelerate the process of carrying out the task and this confidence will grow if there is strong encouragement and motivation from the surrounding environment and especially the leadership.

Also related to organizational support, the confidence to complete the work the things that are most considered by members of the TNI are still considered to be improved. Organizations are expected to be able to provide tangible support to members of the TNI to be able to complete their work well. One form of effort that can be done is the existence of balanced performance incentives for each member of the TNI who is achieving. Related to the performance of members of the TNI itself, an indicator of performance that has not been achieved well is the ability to achieve the targets set by the organization. This can be encouraged by the presence of greater leadership in the ability to motivate members of the TNI to be more enthusiastic and have high confidence in their work. Furthermore, related to organizational performance, territorial development is a program that is considered very important and must be carried out sustainably.

\section{References}

1) Anwar. (2012). Pengaruh Gaya Kepemimpinan Terhadap Kinerja Pegawai Pada Biro Administrasi Universitas Hasanuddin Makassar. Sekolah Tinggi Ilmu Administrasi Lembaga Administrasi Negara, Makassar.

2) Avolio, B. J., Bass, B. M., \& Jung, D. I. (1999). Replicated confirmatory factor analyses of the multi-factor leadership questionnaire. Binghamton. Joumal of Occupational and Organisational Psychology, 72, 441-462.

3) Chiang, C.-F., \& Hsieh, T.-S. (2012). The impacts of perceived organizational support and psychological empowerment on job performance: The mediating effects of organizational citizenship behavior. International Journal of Hospitality Management, 31(1), 180-190. https://doi.org/https://doi.org/10.1016/j.ijhm.2011.04.011

4) Darolia, C. R., Kumari, P., \& Darolia, S. (2010). Perceived Organizational Support, Work Motivation, and Organizational Commitment as determinants of Job Performance. Journal of the Indian Academy of Applied Psychology, 36(1), 69-78.

5) Dessler, G. (2003). Manajemen Sumber Daya Manusia. Jakarta: PT Indeks.

6) Fahmi, H. K., Musnadi, S., \& Nadirsyah. (2019). Role Conflict, Self Efficacy, Employees' Performance and Organizational Performance. Journal of Accounting Research, Organization and Economics, 2(1), 31-40. https://doi.org/10.24815/jaroe.v2i1.13013

7) Ferdinand, A. (2006). Metode Penelitian Manajemen Pedoman Penelitian untuk Penulisan Skripsi Tesis dan disertai Ilmu Manajemen. In Semarang: Universitas Diponegoro. Semarang: Fakulas Ekonomi dan Bisnis Univ Diponegoro.

8) Gibson, J., Ivancevic, J., \& Konopaske, R. (2012). Organizations: Behavior, Structure, Processes (14th ed.). New York: Mc Graw Hill.

9) Hasibuan. (2014). Manajemen Sumber Daya Manusia. In Manajemen Sumber Daya 
Manusia (Revisi). Jakarta: Bumi Aksara.

10) Ihya, Adam, M., \& Nurdin, R. (2019). The Influence of Individual Characteristics, Organizational Characteristics and Work Environment on Employee Performance and Its Impact on the Performance of Bkkbn Representative Organization of Aceh Province. International Journal of Business and Social Science, 10(5), 95-107. https://doi.org/10.30845/ijbss.v10n5p10

11) Kurtessis, J. N., Eisenberger, R., Ford, M. T., Buffardi, L. C., Stewart, K. A., \& Adis, C. S. (2015). Perceived Organizational Support: A Meta-Analytic Evaluation of Organizational Support Theory. Journal of Management, $x x(\mathrm{x}), 1-31$. https://doi.org/10.1177/0149206315575554

12) Ling, V. M., Lo, M. chiun, Sing, N. K., \& Ayob, N. (2010). The influence of leadership styles on employees' job satisfaction in public sector organizations in Malaysia. International Journal of Business, Management and Social Sciences, 2(1), 24-32.

13) Pasolong, H. (2010). Teori Administrasi Publik, Alfabeta. Bandung: Alfabeta.

14) Prawirosentono, S. (2010). Manajemen Sumberdaya Manusia: Kebijakan Kinerja Karyawan: Kiat Membangun Organisasi Kompetitif Era Perdagangan Bebas Dudia. Yogyakarta: BPFE.

15) Ritonga, M. W. A. N., Ibrahim, M., \& Bahri, S. (2019). The Practice of Work Culture, Suitability of Tasks, Leadership Style That has an Impact on Performance: The Role of Job Satisfaction as Mediating. International Journal of Research in Business and Social Science, 8(4), 2147-4478.

16) Robbins, S. P., \& Judge, T. A. (2012). Organizational Behavior (15th ed.; S. Yagan, Ed.). San Diego: Pearson.

17) Usman, H. (2012). Manajemen: Teori, Praktik, dan Riset Pendidikan (4th ed.). Jakarta: Bumi Aksara.

18) Yukl, G. (2010). Leadership in Organizations. In The British Journal of Psychiatry (Seventh Ed, Vol. 112). https://doi.org/10.1192/bjp.112.483.211-a

\section{Works Cited}

Mahesa Fitriadi, Muhammad Adam, Mukhlis. (2021). The Effect of Transformational Leadership and Organizational Support on Member Performance and Its Impact on Performance: Study in Kodam Iskandar Muda. International Journal of Scientific and Management Research, 04(05), 201-213. doi:http://doi.org/10.37502/IJSMR.2021.4513 